\title{
MUSIC AND RELIGION IN THE FIRST WORLD WAR
}

\author{
by STUART MEWS
}

-T ISTENING to instrumental music has really become the only form of worship which is still possible to us.' These words, said to have been uttered by a distinguished Oxford philosopher, were quoted by Hastings Rashdall, then an Oxford theologian but later Dean of Carlisle, when he preached in Hereford Cathedral in connection with the Three Choirs Festival in 191 2. ${ }^{1}$ Rashdall rejected the substitution of aesthetic appreciation in the concert hall for Christian worship because, he contended, it did not evoke any practical response. That he should have felt it necessary to stress this difference was in itself evidence of the strength of the view he was repudiating. It was also a significant comment on the secularization of the English academic profession and perhaps of a wider section of the middle class. It is a reminder, too, of suggestions made by scholars of history, sociology, and anthropology that there are significant connections and similarities between the development and social functions of music and religion. H. G. Koenigsberger has argued that the decline of religion left an emotional void in Western Europe which came increasingly to be filled primarily by music. ${ }^{2}$ David Martin points out that both music and religion serve similar purposes, 'such as orgiastic stimulation, group solidarity, martial sentiment'. ${ }^{3}$ J.S. Eades begins with the view that both 'artistic performance and religious ritual may be symbolic expressions of solidarities which can be used for political ends." 4

Rashdall's warning might also be taken as a comment on the quality of the services in many churches at the time, both those which were for a variety of social and cultural reasons slowly losing support, but also those

1 Oxford, Pusey House, Hastings Rashdall MS, sermon T.22I.

2 H. G. Koenigsberger, 'Music and Religion in Modern European History', in H. G. Koenigsberger and J. H. Elliotr, eds, The Diversity of History (London, 1973), pp. 35-78. See also George Whitfield Andrews, 'Music as an expression of religious feeling', Musical Quarterly, 2 (1916), pp. 33 If. Sir Adrian Boult, 'Preface' to K. W. S. Mendl, The Divine Quest in Music (London, 1957), p. ix.

${ }^{3}$ David Martin, Tracts against the Times (London, 1973), pp. 171f.; The Religious and the Secular (London, 1969), pp. 79-99; "Music and religion: ambivalence towards the "Aesthetic"; Religion, 14 (1984), pp. 269-94.

4 J. S. Eades, "Dimensions of meaning: Western music and the anthropological study of 
which attempted to combat this decline by expanding the musical part of the service. That this was at all possible was due to the extraordinary revitalization of musical life in late Victorian society. At the inauguration of the Royal College of Music in 1882 W. E. Gladstone had said of church music fifty years before, 'I cannot use any epithet weaker than one that

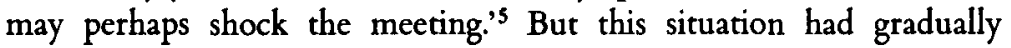
changed. What Helen Mellor has called 'the passion for music' began in socio-religious circles. ${ }^{6}$ The sight-singing 'mania' was immensely boosted by the German political refugee, ex-Catholic priest, and temperance advocate Joseph Mainzer, who began to hold singing classes in London in I84I. His message that choirs were more wholesome than pubs for working people was made more realistic when a Congregationalist minister John Curwen popularized the tonic sol-fa method of sight-reading. ${ }^{7}$ The result was a vast increase in choral singing and a more widespread appreciation of high musical standards.

Though music-making received encouragement from religious groups, it could not be controlled by them. Relations between composer and divine, organist and priest, were always fragile, and never more so than at the turn of the century, when higher professional standards and status created the possibility of resentment when their respective spheres overlapped. Ralph Vaughan Williams was dismissed as organist of a church in South Lambeth in 1897 because he refused to take Communion. ${ }^{8}$ Soon after his arrival at St Margaret's, Westminster, in 1900 Hensley Henson got rid of the organist because he feared that musical showmanship was eclipsing the sermon. ${ }^{9} \mathrm{~J}$. G. Simpson lectured Henry Thompson, music critic of the Yorkshire Post, in 1908, after being criticized in the paper for a comment in a sermon in Leeds Parish Church about the inappropriateness of Brahm's German Requiem to the season of Advent. 'What I dislike', he wrote, 'is the unintelligent conclusion that, because Brahms has got something to do with Death, and because Spohr calls itself the Last Judgment, that therefore they must be appropriate to this season.

symbolism', in J. Davis, ed., Religious Organization and Religious Experience $=$ ASA Monograph, 31 (London, 1982), p. 195.

3 The Times, I March I 882.

- H. E. Mellor, Leisure and the Changing City, 1870-1914 (London, 1976), p. 219.

'Joseph Mainzer, Music and Education (London and Edinburgh, 1848); William J. Gatens, Victorian Cathedral Music in Theory and Practice (Cambridge, 1986).

' Michael Kennedy, 'The Unknown Vaughan Williams', Proceedings of the Royal Music Association, 99 (1972), p. 34.

$\rightarrow$ H. Hensley Henson, Retrospect of an Unimportant Life (Oxford, 1942), p. I 31. 


\section{Music in the First World War}

I do not mean to say that you are unintelligent! But I am afraid that the choice of music "in choirs and places where they sing" often is.' ${ }^{10}$

Concern about the role of music in worship went beyond the Church of England. In 1904 the Pope issued the encyclical De motu proprio aimed at pruning severely the efflorescence of banal and turgid music in the Catholic Church and restoring those qualities of 'holiness, beauty and universality' which were thought to find their most appropriate musical expression in the Gregorian chant." In England, Pius X's reforms had already been anticipated at Westminster Cathedral by Richard Terry, who in his writings and performance demonstrated that plainsong music 'need not be cold, unrhythmic, and lifeless'. 'At Westminster', commented an attender at a Holy Week seivice in I91 5, 'the music lived, like the faces of old burghers in a masterpiece of Rembrandt, or the dark, beady eye of a Rubens portrait. 12

The First World War, as Professor John Sommerville has pointed out, 'does seem to have been something of a turning-point' in the development of religious themes in music. The war, he maintains, 'forms a divide between a period of a somewhat frivolous religious reference, and one of a more austere and introspective tone. ${ }^{13}$ His article focuses mainly on post-war compositions by internationally-known musicians. This article looks at some of the more immediate responses of mainly lesser mortals who found themselves crossing the boundaries between music and religion between 1914 and 1918.

The outbreak of war presented a challenge to both the religious and musical worlds. For musicians the immediate practical effect was to disrupt concert programmes and deplete audiences and orchestras. To meet this situation a Committee for Music in War Time was formed, though its primary function was more accurately revealed in June 1915 when it amalgamated with the Professional Classes War Relief Fund. The Musicians' section retained its separate identity under the chairmanship of Sir Hubert Parry and included on its committee most of the illustrious names in British music: Edward Elgar, Henry Wood, C. V. Stanford,

${ }^{10}$ Leeds, Brotherton Library, MS 361/24I, J. G. Simpson-H. T. Thompson, 4 Dec. 1908.

11 'Motu Proprio of Pope Pius X on Sacred Music', in Nicolas Slominski, ed., Music since 1900, 4th edn (London, 1971), pp. 1285-9; Anthony Milner, 'Music in a vernacular Catholic liturgy', Proceedings of the Royal Music Association, 91 (1964), p. 27.

12 Joseph W. Hathaway, 'Modern Church Music', Music Student, April 1915, p. 105: R. R. Terry, Our Church Music (London, 1901); Catholic Church Music (London, 1907).

$13 \mathrm{C}$. John Sommerville, 'The religious music of the twentiech and twenty-first centuries', Religion, 14 (1984), p. 247. 
Walford Davies, Frederick Bridge, and Vaughan Williams. Its object was to 'develop schemes for the employment of people in the musical world during the war, and to deal with cases of distress'. In the first six months, from January to June 1915,176 concerts had been given in hospitals, 89 in army camps, and 124 in clubs, schools, and other places. Commanding officers, chaplains, and hospital matrons were all agreed on the inspiring and elevating effects of the concerts upon recruits in training, and the fillip they gave to soldiers and sailors convalescing after being wounded in action. ${ }^{14}$

Rudyard Kipling was the chief speaker at a meeting at the Mansion House on 27 January i9is to promote the formation of bands as recruiting agents. His description of the social function of the band was very similar to that which, two years before, the French sociologist Emile Durkheim had ascribed to religion. The band, said Kipling, 'revives memories, it quickens associations, it opens and unites the hearts of men more surely than any other appeal ... the magic and the compelling power are there to make men's souls realize certain truths which their minds might doubt.' Kipling went on to argue that the best expression of the 'soul of the battalion' was often to be found in the band, which provided a 'common means of expressing and interpreting the thoughts and feelings of the battalion'. ${ }^{15}$ It was not difficult, recalled John Rogan, bandmaster of the Coldstream Guards, 'to get a man to give his life for his country by appealing to his heart through his national airs.' ${ }^{16}$ It was even easier to use band concerts to persuade businessmen in the city to invest in War Loan.

In June I915, a month in which the whole nation was being goaded into making greater efforts to concentrate all the nation's latent powers on the defeat of the enemy, The Times weighed in with an article on 'The Mobilization of Music'. ${ }^{17}$ It was no coincidence that this slogan was being used at exactly the same time as the Bishop of London. A. F. Winnington Ingram, was calling for the mobilization of the nation's spiritual resources in a 'holy war'. ${ }^{18}$ The Times article drew a letter from Walford Davies, organist at the Temple Church, on 'the vital uses of music in wartime'. He had been told by a man on leave after eight months in the trenches that 'fragments of familiar music come as the greatest help in hard times.'

14 Musical Times, 1 July I9I s, pp. 393 f.

is Ibid., I March 191 S, p. I 47.

16 John Mackenzie-Rogan, Fifty Years of Ammy Music (London, 1926), p. 185.

17 The Times, 12 June I91 s.

18 Stuart Mews, 'Spiritual mobilization in the First World War', Theology (1971), pp. 258-64. 
What was needed for the troops, Davies claimed, was 'a little first-rate music' and songs that can be easily remembered. ${ }^{19}$

The First World War produced an abundance of songs which could be sung. As well as the quasi-religious sentimentality of Ivor Novello's 'Roses of Picardy' and 'Keep the Home Fires Burning', there was the use of wellknown hymn tunes for rough rhymes of a blasphemous character. Samuel Sebastian Wesley's tune Aurelia, which usually accompanied 'The Church's one foundation' now had a new set of words, 'We are Fred Karno's army', while the tune used for 'What a friend we have in Jesus' had an even more obscene version. Protests to the Archbishop of Canterbury were of little avail, for he could not think of any way in which he could censor the soldiers' songs. ${ }^{20}$ This desecration or secularization of the music of the Church was in some instances a case of the wheel turning full circle. Henry Hall, the well-known band leader of the inter-war years, had no knowledge of popular music until he served in the Army. He had been brought up in the Salvation Army and worked with his father in the Music Department at Salvation Army headquarters. The effect of military service was to broaden his horizons and sever him from his religious roots. As the only pianist in his company, he was soon being called upon to improvise ragtime tunes, and responded by converting Salvation Army tunes into popular hits. The theme tune for his wireless programme was called 'Here's to the next time', but had been composed as a Salvation Army march before the war. ${ }^{21}$ So the wheel turned full circle. General Booth had taken the devil's best tunes and baptized them, and within ten years of the founder's death, his tunes were in turn being handed back to Mammon.

Concerts at army bases were immensely popular. Soldiers, whose lives alternated between brutality, exhaustion, and boredom relished good music and poetry. At first the actress Lena Ashwell had had every obstacle put in her path when she attempted to take concert parties to the front. Indeed, the Army, which thought they were engaged in a war of movement, had even less time for performers than for chaplains; and at first not much time for them either. Only by pulling royal strings were concert parties allowed out, ${ }^{22}$ and only then under the unlikely umbrella of the YMCA, an organization which before 1914 was associated with narrow

19 The Times, 17 June igrs.

${ }^{20}$ E. D. Mackerness, A Social History of English Music (London, 1964), p. 140.

${ }^{21}$ Henry Hall, Here's to the Next Time (London, 1955), p. 31.

22 Lena Ashwell, Myself a Player (London, 1936), p. 195. 
evangelical attitudes. ${ }^{23}$ Lena Ashwell imagined that most of the YMCA leaders looked upon the theatre, 'which they had never entered, as the front door of Hell where painted females devoured the souls of the righteous'. 24 'To them we are a class of terribly wicked people who drink champagne all day long, and lie on sofas, receiving bouquets from rows of admirers. ${ }^{25}$ She amused herself by conjuring up the fantasies of YMCA staff, who probably 'expected us to land in France in tights, with peroxide hair, and altogether to be a difficult thing for a religious organisation to camouflage. 26

The concert parties organized by Lena Ashwell usually consisted of a soprano, contralto, tenor, baritone or bass, instrumentalist, entertainer, and accompanist. She found an increasing demand for depth. 'We all sing rot at first and end by finding they have better taste', recorded Madelaine O'Connor, a singer and lecturer, who worked for the YMCA at the base in Rouen. ${ }^{27}$ She urged Lena Ashwell to recite 'something good'. Lena responded by offering 'Abou Ben Adhem' and Elizabethan love lyrics, and 'was very much astonished at the deep interest and very real response of the men'. ${ }^{28}$ 'In a crowded hut or tent filled with smoke and packed to suffocation', she recalled, 'one felt the hunger of the souls of men, the aching, wondering query in their hearts. ${ }^{29}$

Good music was even more evocative than fine poetry. 'We suffered a good deal from want of music', wrote Canon J. O. Hanney, after being chaplain at a base in France. ${ }^{30}$ Lena Ashwell considered that of all the singers who went out with her concert parties, the most appreciated was Gervase Elwes. ${ }^{31}$ In June 1917 he sang at a rest camp at Equihen in terrific heat: 'I shall never forget the experience as long as I live', he wrote home, 'never have I sung to such an audience. ${ }^{32}$ The night before the legendary T. B. Hardy left the base for the firing line he was overcome by a tenor singing in a concert. He later explained that he left after the song because

${ }^{23}$ Clyde Binfield, George Williams and the Y.M.C.A. A Study in Victorian Social Attitudes (London, 1973), ch. 14.

24 Ashwell, Myself a Player, pp. I97f.

2s Lena Ashwell, Modern Troubadours. A Record of the Concerts in France (Copenhagen, 1922), p. 7.

26 Ibid., p. 7 .

27 lbid., p. 15.

28 Ibid., p. 14.

29 Ibid., p. 12.

30 George A. Birmingham (pseudonym for James O. Hanney), A Padre in France (London, n.d.), p. 73 .

31 Ashwell, Myself a Player; p. 206.

32 Winifred Elwes and Richard Elwes, Gervase Elwes. The Story of his Life (London, 1935), p. 249. 


\section{Music in the First World War}

he wanted to keep the memory of it in his mind when he was in the line. ${ }^{33}$ 'Next to religion', commented J. O. Hanney, '... music is probably the most powerful means we have of spiritual treatment..

In her eagerness to legitimize the stage and concert-hall, Lena Ashwell probably exaggerated both the narrow-mindedness of YMCA staff and the spiritual appeal of performers. After three months of war, Sir Herbert Lewis, the deeply devout Liberal MP for Flintshire, made his own enquiries. 'The theatrical people had been contending that the men were getting tired of the YMCA sing songs and wanted some more exciting entertainments which only theatrical people could supply.' Investigations 'convinced me that all YMCA tents were full to overflowing every night. ${ }^{33}$ Nevertheless, Arthur Burroughs, YMCA lecturer at Rouen, and a future bishop, was probably correct when he stated in 1916 that 'religious meetings were never anything like so popular as concerts. ${ }^{36}$ This inevitably led to friction, and an attempt by the YMCA to take over the concerts. This Lena Ashwell defiantly resisted. ${ }^{37}$ But in wanting to take control the YMCA was recognizing the power of the performing arts, and in doing so overcoming in the minds of its members a barrier which had long existed. 'So many of those working with the YMCA', according to Lena Ashwell, 'who had never been to a play' took to them 'like ducks to water', and went on to become enthusiasts for 'sound and wholesome recreations for the people' ${ }^{38}$

As the months passed, it became obvious that the war was going to last longer than anyone imagined. An antipathy to all things German now began to pervade the nation. Pulpit and press thundered against the poisoned products of German Kultur, and in the summer of I9Is, when the rumours of German atrocities appeared to have been authenticated by the Bryce Report and the message rubbed home by the sinking of the Lusitania, there came demands for the boycotting of German music. In the House of Commons, Sir Arthur Markham raised what he considered to be the scandal of the inclusion by Sir Henry Wood of German music in his Promenade Concerts. ${ }^{39}$ Sir Walter Parratt, Master of the King's

\footnotetext{
${ }^{33}$ Ashwell, Modem Troubadours, p. I 34. For a recent interpretation of this amazing man: David Raw, 'It's Only Me' A Life of the Reverend Theodore Bayley Hardy, V.C., D.S.O., M.C. $1863-1918$ (Gatebeck, 1988).

34 Birmingham, Padre, p. 77.

${ }^{35}$ Plas Penucha (courtesy of Mrs K. Idwal Jones), MS Diary of Sir Herbert Lewis, 14 Nov. 1914.

36 E. A. Burroughs, The Valley of Decision (London, 1916), p. 197.

37 Ashwell, Modern Troubadours, p. 132.

19. Ibid.,p. 7.

39 PD, LXX, col. 2326, Musical Times, I Sept. 1915.
} 
Musick, and organist of St George's Chapel, Windsor, tried hard to show the absurdity of the demand for the boycott of all German music. To do so would mean expurgating many of the most popular tunes used in English churches. He refused to believe that Cruger's seventeenth-century tune Nun danket, associated with 'Now thank we all our God', would be readily discarded. 'In all my musical activities', wrote Parratt, 'I have taken no notice of the war. Music is cosmopolitan. ${ }^{40}$ Such Olympian detachment, however, shocked those who held that musicians should be involved in the national struggle. Both in London and the provinces, festivals of British music were being mounted, and towards the end of I 9 I 5 vigorous protests were made at the use of foreign music at funerals of the famous. Sir Charles Stanford wrote to The Times objecting to the use of Russian music at the memorial service for Lord Roberts at St Margaret's, Westminster. His former pupil, Martin Shaw, organist at St Mary's, Primrose Hill, protested in The Church Times against the selection of music by foreign composers at the memorial service for Edith Cavell in St Paul's Cathedral.41

The war gave a tremendous boost to those like Martin Shaw, who had long wished to liberate British composers from European and especially German influence. In August 1916 Shaw interrupted his honeymoon to lecture on 'The Church and National Music' at the Welsh Church Music Conference in Aberystwyth. ${ }^{42}$ An ardent patriot, who compensated for his rejection for military service by drilling the choirboys at St Mary's, Primrose Hill, ${ }^{43}$ he began by asserting that the Germans had already won their cultural war against England. The average child's life, he said, began by associating Christmas with the German Santa Claus; his first school was directly copied from Germany and called a Kindergarten. He was taught 'almost exclusively' at school both to sing and play German tunes until he married to the strains of Mendelssohn and Wagner. If he achieved eminence, his death would be honoured with a German dead march.

'Now the Germans', asserted Shaw, 'are a very thorough nation.' He considered it likely that they had all along been planning not only a war of weapons against England, but also a war of ideas. 'I mean the insidious force that conquers us mentally and undoubtedly is part of that system of "peaceful penetration" which the Germans have been organizing in the

\footnotetext{
40 Sir Walter Parratt, 'Our German Church Music', Monthly Musical Record, I July 1916.

41 The Times, 16 Nov., Church Times, 19 Nov., Musical Times, I Dec. Igrs.

42 Martin Shaw, Up to Now (Oxford, 1929), p. 132.

43 Ibid., p. 123.
} 


\section{Music in the First World War}

British Isles for many years.' Having detected the presence of these subversive influences, Shaw summoned the Church to react. In the struggle for freedom of mind and spirit, he believed that the Church had a vital part to play because he claimed that the Church was the only remaining stronghold of national music.

The true music of the people of these islands is to be found not in the streets or music halls-there it is debased beyond recognition; not on the concert platform, the public school, the home-there it is either alien or full of that sloppy sentimentality which we would be the first to condemn in actual life; no, the true music of the people can only be found in the church, and that too rarely.

The academies and colleges of music had in Shaw's view surrendered, but although 'Germanism', by which he meant the influence of Handel and Mendelssohn, might predominate, it had not entirely driven the native idiom from English Church music. Now that the war had revealed the true state of things to everyone, he challenged organists and clergy to take a deliberate decision to expunge foreign elements in music and to follow the French, and even more the Russians, in drawing nourishment from the native tradition instead of 'filching fruit from our neighbour's garden'.4

This onslaught on the alleged German cultural capture of church music did not come solely from the Anglican Martin Shaw. Indeed, the most savage attack of all came from the Roman Catholic Richard Terry, Director of Music at Westminster Cathedral. Terry had been for years the leading English champion of the restoration of plainsong and a strong advocate of the revival of Tudor music. The war provided him with an excellent opportunity to promote his enthusiasms. Germany, he claimed in August 1915, had captured the Catholic church music market 'to her commercial profit and to our artistic degradation'. His indictment was directed towards the Cecilian Movement as it developed after the death of Franz Witt in 1888 . Terry conceded that a debt was owed to the Germans, particularly Carl Proske of Ratisbon, who had begun in 1830 to collect and score large quantities of beautiful but neglected music. 'The old ideals of church music-dignity, sobriety and liturgical fitness were revived', Terry admitted. 'But that was before $1870-$ before Germany turned from

4 Martin Shaw, 'The Church and National Music', Musical Opinion and Music Trade Review, Nov. 1916, pp. 91-2. 
greatness in search of bigness, before she forsook idealism for commercialism.' Under Dr F. Habl, Director of the Ratisbon School of Sacred Music, vast quantities of dull, monotonous, uninspired 'Cecilian' music poured from the press. 'As usual', commented Terry, 'John Bull fell an easy victim to Teutonic wiles.' Branches of the Cecilian Society were established in England, Ireland, and the United States, 'with the richest results' for the pockets of the German publisher. The consequence was 'the abiding presence in Church music circles of an aggressive Potsdam party'. Cecilian church music reform was, in Terry's view, 'nothing more than a trade, a trade masquerading in the name of Religion and Art'. Germany's mission since 1870 , he concluded 'has been to supply foreign nations with the cheapest shoddy they would put up with, and her Cecilian wares are the cheapest shoddy that ever debased the name of music." ${ }^{\text {"5 }}$

Terry's diatribe provoked a lively correspondence in The Tablet, in which his knuckles were soundly rapped by protagonists of Cecilian music, such as Canon Henry Parkinson, of Oscott College, and James Britten, the lay Catholic Truth Society apologist. ${ }^{46}$ Both objected to the manipulation of prejudices aroused by the war to influence judgements which should be made on grounds of scholarship and taste. Nor did they take kindly to being described as 'the Potsdam party' of the English church musical world.

Martin Shaw and Richard Terry had causes to plead, and were perhaps no more than the most strident representatives of a trend, but perhaps their vigorous campaigning in the war years played some small part in creating a greater readiness for the characteristic 'English' style of music which became popular in the 1920 s and 1930s. But in their zeal to promote their cause it really was not necessary to be so fanatically antiGerman. Musicians had no need to be more patriotic than the Government.

On 5 August 1914, the day after the British declaration of war, the Foreign Secretary, Sir Edward Grey, wrote to the singer Campbell McInnes, 'I love Handel's music and it does me good. Europe is in the most terrible trouble it has ever known in civilised times and no one can say what will be left at the end. But Handel's music will survive. ${ }^{17}$ Later in the war, Grey returned to the same theme:

45 R. R. Terry, 'Sidelights on German Art: The great church-music imposture', Musical Times, I Aug. I9Is.

t6 The Tablet, 14, 22 Aug., 4 Sept. 1915 . Terry replied in Musical Times, I Dec. 1915.

47 G. M. Trevelyan, Grey of Falloden (London, 1948), p. 159. 


\section{Music in the First World War}

I think it is a good and wholesome check upon the horror cast by war to think of the things that even the war cannot shake or alter. Great music loses none of its power, but it must be great like the 'Messiah' or a Beethoven symphony. I am sure these things have the eternal in them. ${ }^{48}$

\section{University of Lancaster}

4 Ibid., p. 342. 